\title{
Platelet Protein Phosphorylation, Elevation of Cytosolic Calcium, and Inositol Phospholipid Breakdown in Platelet Activation Induced by Plasmin
}

\author{
Andrew I. Schafer, Ann K. Maas, J. Anthony Ware, Peter C. Johnson, Susan E. Rittenhouse, and Edwin W. Salzman \\ Hemostasis Unit and Hematology Division, Department of Medicine, Brigham and Women's Hospital, the Department of Surgery, Beth \\ Israel Hospital, and Harvard Medical School, Boston, Massachusetts 02115
}

\begin{abstract}
Studies have been performed on the biochemical mechanism of platelet activation induced by the fibrinolytic protease plasmin. In washed human platelets, $\geq 1.0$ caseinolytic units $(\mathrm{CU}) / \mathrm{ml}$ plasmin induced aggregation. Platelet $\left[{ }^{14} \mathrm{C}\right]$ serotonin release was stimulated by $1.0 \mathrm{CU} / \mathrm{ml}$ plasmin to an extent comparable to that induced by $1.0 \mathrm{U} / \mathrm{ml}$ thrombin. A dose- and time-dependent phosphorylation of the platelet 47,000 - and $20,000-\mathrm{kD}$ proteins was noted in ${ }^{32} \mathrm{PO}_{4}$-labeled platelets incubated with plasmin; phosphorylation was not affected by extracellular $\mathrm{Ca}^{2+}$, but was completely inhibited by an increase in platelet cyclic AMP. Phosphorylation of these platelet proteins suggested that plasmin may act on platelets by stimulating a rise in cytosolic calcium concentration $\left(\left[\mathrm{Ca}_{\mathrm{i}}{ }^{2+}\right]\right)$ and activating inositol phospholipid-dependent phospholipase $\mathrm{C}$ and protein kinase $\mathrm{C}$. Using both quin2 fluorescence and aequorin luminescence as indicators, plasmin was found to elevate platelet $\left[\mathrm{Ca}_{1}{ }^{2+}\right]$ in the presence or absence of extracellular $\mathrm{Ca}^{2+}$. Phospholipase $\mathrm{C}$ activation was shown by the generation of $\left[{ }^{3} \mathrm{H}\right]$ diglyceride in $\left[{ }^{3} \mathrm{H}\right]$ arachidonic acid-labeled platelets and $\left[{ }^{32} \mathrm{P}\right]$ phosphatidic acid in ${ }^{32} \mathrm{PO}_{4}$ labeled platelets exposed to plasmin. Plasmin did not induce formation of thromboxane $A_{2}\left(T X A_{2}\right)$. Only small amounts of this eicosanoid were detected late in the time course after plasmin stimulation. Our results indicate that plasmin causes platelet aggregation and secretion associated with phosphorylation of the 47,000- and 20,000-kD proteins, $\mathrm{Ca}^{2+}$ mobilization, and phospholipase $\mathrm{C}$ and protein kinase $\mathrm{C}$ activation.
\end{abstract}

\section{Introduction}

Plasmin is the protease of the fibrinolytic system that is formed by the proteolytic action of plasminogen activators on the circulating zymogen plasminogen (1). Important interactions have been reported between plasmin and platelets, with which fibrin forms the hemostatic plug. Treatment of platelets with plasmin in vitro leads to the loss of platelet membrane glycoprotein Ib, a surface receptor for von Willebrand's factor (2). We have recently shown that incubation of platelets with plasmin at concentrations $<0.5$ caseinolytic units $(\mathrm{CU})^{1} / \mathrm{ml}$, which do not affect

Address reprint requests to Dr. Schafer, Brigham and Women's Hospital, 75 Francis Street, Boston, MA 02115.

Received for publication 11 September 1985 and in revised form 1 April 1986.

1. Abbreviations used in this paper: $\left[\mathrm{Ca}_{\mathrm{i}}{ }^{2+}\right]$, platelet ionized calcium concentration; CTA, Committee on Thrombolytic Agents; CU, caseinolytic units; DAG, 1,2-diacylglycerol; DG, diglyceride; IP $_{3}$, intracellular my-

J. Clin. Invest.

(C) The American Society for Clinical Investigation, Inc. $0021-9738 / 86 / 07 / 0073 / 07 \$ 1.00$

Volume 78, July 1986, 73-79 platelet shape change, aggregation or release, results in the doseand time-dependent inhibition of platelet aggregation and thromboxane $A_{2}$ production in response to thrombin, collagen and calcium ionophore A23187 and the thrombin-induced release of $\left[{ }^{3} \mathrm{H}\right]$ arachidonic acid from membrane phospholipids, although exogenous arachidonate-stimulated aggregation and thromboxane generation were not blocked by preincubation with plasmin (3). We now report that at higher concentrations, plasmin acts as a platelet agonist, stimulating rather than inhibiting platelet responsiveness.

The mechanism of surface signal transduction in platelets and other cells has been the subject of several recent reviews (4, 5). Platelet activation by various extracellular signals is mediated by an increase in the cytosolic $\mathrm{Ca}^{2+}$ concentration $\left(\left[\mathrm{Ca}_{\mathrm{i}}{ }^{2+}\right]\right)$. The mechanism of cellular response may involve a calmodulin-dependent activation of myosin light chain kinase, which leads to phosphorylation of the $\sim 20,000-\mathrm{kD}$ light chains of myosin. In addition, a variety of biologically active substances exert their effects on platelets by interactions with specific cell surface receptors that induce the turnover of plasma membrane inositol phospholipids. The agonist-mediated breakdown of phosphatidylinositol 4,5-bisphosphate $\left(\mathrm{PIP}_{2}\right)$ by phospholipase $\mathrm{C}$ generates two intracellular "messengers": myoinositol 1,4,5-triphosphate $\left(\mathrm{IP}_{3}\right)$, which causes intracellular $\mathrm{Ca}^{2+}$ mobilization, and 1,2-diacylglycerol (DAG), which activates protein kinase $\mathrm{C}$ to phosphorylate an endogenous platelet protein of $\sim 47,000 \mathrm{kD}$. Maximal biologic effect has been considered to result from the synergistic actions of $\mathrm{Ca}^{2+}$ mobilization and receptor-linked inositol phospholipid breakdown and protein kinase $\mathrm{C}$ activation. In platelets, free arachidonic acid is produced from inositol phospholipids through consecutive reactions catalyzed by phospholipase $\mathrm{C}$ and diacylglycerol lipase. After conversion of DAG to phosphatidic acid, a specific phosphatidic acid lipase can also release free arachidonic acid. Furthermore, arachidonic acid can be hydrolyzed from phosphatidylcholine and phosphatidylethanolamine by phospholipase $A_{2}$. Free arachidonic acid is rapidly oxygenated to a variety of biologically active eicosanoids, including thromboxane $A_{2}$, a potent inducer of platelet aggregation and vasoconstrictor.

We now report that plasmin causes platelet aggregation and secretion, which are associated with phosphorylation of both the 20,000 - and $47,000-\mathrm{kD}$ proteins, calcium mobilization, and phospholipase $\mathrm{C}$ activation.

\section{Methods}

Plasmin preparation. Plasmin was dissolved in $10 \mathrm{mM}$ Tris, $150 \mathrm{mM}$ $\mathrm{NaCl}, \mathrm{pH} 7.4$, and stored in aliquots at $-40^{\circ} \mathrm{C}$. CU were defined according

oinositol 1,4,5-triphosphate; PA, phosphatidic acid; PAGE, polyacrylamide gel electrophoresis; $\mathrm{PGE}_{1}$, prostaglandin $\mathrm{E}_{1} ; \mathrm{PIP}_{2}$, phosphatidylinositol 4,5-biphosphate; PRP, platelet-rich plasma; TLC, thin-layer chromatography; $\mathrm{TXA}_{2}, \mathrm{TXB}_{2}$, thromboxane $A_{2}$ or $\mathrm{B}_{2}$. 
to Sgouris et al. (6): $1 \mathrm{CU}$ equals 1.14 CTA (Committee on Thrombolytic Agents) units (7). Plasmin activity was determined in an S-2288 chromogenic substrate assay following the manufacturer's method (8). The assay was performed at $37^{\circ} \mathrm{C}$ in a spectrophotometer equipped with a recording chart (Gilford 2400, Gilford Instruments, Oberlin, OH). Kinetic data supplied by the manufacturer indicate that, for a substrate concentration of $1 \times 10^{-3} \mathrm{~mol} /$ liter and a plasmin concentration of $4 \times 10^{-9}$ $\mathrm{mol} / \mathrm{liter}, \Delta \mathrm{A} / \mathrm{min}$ at $405 \mathrm{~nm}$ is $0.042 .1 \mathrm{CU}$ plasmin $=\sim 0.45 \mathrm{nmol}$ plasmin.

Human plasmin subjected to $10 \%$ sodium dodecyl sulfate (SDS)polyacrylamide gel electrophoresis (PAGE) produced two major bands with apparent molecular masses of 70,000 and 28,000 under reducing conditions, and a single band with an apparent molecular mass of 81,000 under nonreducing conditions.

Platelet aggregation. Venous blood anticoagulated with $13 \mathrm{mM}$ sodium citrate was obtained from volunteers who had not ingested aspirin or other medications known to interfere with platelet function for at least $10 \mathrm{~d}$ prior to donation. Blood was centrifuged at $160 \mathrm{~g}$ for $10 \mathrm{~min}$ to obtain platelet-rich plasma (PRP). Platelets were separated from plasma by gel filtration by applying PRP to a column of Sepharose 2B. The platelets were eluted with a modified Tyrode's buffer containing 130 $\mathrm{mM} \mathrm{NaCl}, 9 \mathrm{mM}$ sodium bicarbonate, $6 \mathrm{mM}$ dextrose, $10 \mathrm{mM}$ sodium citrate, $10 \mathrm{mM}$ Trizma base, $0.8 \mathrm{mM} \mathrm{KH}_{2} \mathrm{PO}_{4}, 3 \mathrm{mM} \mathrm{KCl}, 0.9 \mathrm{mM}$ $\mathrm{MgCl}_{2}$, and $0.5 \%$ albumin (for aggregation experiments), $\mathrm{pH}$ 7.3. Platelet counts were determined in a model F Coulter Counter (Coulter Electronics, Inc., Hialeah, FL). Aliquots of $0.4 \mathrm{ml}$ of gel-filtered platelets were added to cuvettes containing $\mathrm{CaCl}_{2}(3 \mathrm{mM}$, final concentration). Aggregation was monitored using a standard nephelometric method (9) in a Payton dual-channel aggregometer (Payton Associates, Inc., Buffalo, NY).

Platelet serotonin release. Platelet suspensions in Hepes-Tyrode's buffer containing $10^{-8} \mathrm{M}$ prostaglandin $\mathrm{E}_{1}\left(\mathrm{PGE}_{1}\right)$ were incubated with $3.4 \mu \mathrm{M}\left[{ }^{14} \mathrm{C}\right]$ serotonin, gel-filtered, and serotonin release was measured by a modification of the method of Jerushalmy and Zucker (10). Reactions were terminated with formalin ( $1.5 \%$, final concentration) to stop further release or reuptake of serotonin (11), samples were immediately centrifuged at $8,700 \mathrm{~g}$ for $2 \mathrm{~min}$ in a Beckman Microfuge B (Beckman Instruments, Inc., Palo Alto, CA), and supernatants were counted for released radioactivity. Platelet lysis was determined by ${ }^{51} \mathrm{Cr}$ release, as previously described $(12,13)$.

Platelet ${ }^{32} \mathrm{PO}_{4}$ labeling. Venous blood anticoagulated with $13.5 \%$ acid citrate dextrose (National Institutes of Health Formula A) containing

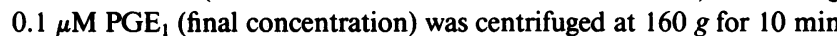
to obtain PRP. The separated PRP was adjusted to $\mathrm{pH} 6.5$ with additional acid citrate dextrose, $10^{-8} \mathrm{M} \mathrm{PGE}_{1}$ (final concentration) was added, and then the PRP was centrifuged at $1,500 \mathrm{~g}$ for $10 \mathrm{~min}$. The plasma supernatant was decanted, $10 \mu \mathrm{l}$ of a solution containing $45 \mathrm{mg} / \mathrm{ml}$ creatine phosphate and $10 \mathrm{mg} / \mathrm{ml}$ creatine phosphokinase was added, and the platelet pellet was resuspended in $1 \mathrm{ml}$ Hepes-Tyrode's buffer containing $130 \mathrm{mM} \mathrm{NaCl}, 9 \mathrm{mM}$ sodium bicarbonate, $6 \mathrm{mM}$ dextrose, $10 \mathrm{mM}$ sodium citrate, $10 \mathrm{mM}$ Trizma base, $3 \mathrm{mM} \mathrm{KCl}, 0.9 \mathrm{mM} \mathrm{MgCl}_{2}, 2 \mathrm{mM}$ Hepes, and $0.1 \%$ gelatin, $\mathrm{pH} 7.4$, and also containing $10^{-8} \mathrm{M} \mathrm{PGE}_{1}$ (final concentration). The suspension of platelets (at $\sim 2 \times 10^{9}$ cells $/ \mathrm{ml}$ ) was incubated with $0.5 \mathrm{mCi}$ of ${ }^{32} \mathrm{PO}_{4}$ at $37^{\circ} \mathrm{C}$ for $60 \mathrm{~min}$, and then gel filtered through a Sepharose $2 \mathrm{~B}$ column equilibrated and eluted with the HepesTyrode's buffer without $\mathrm{PGE}_{1}$. Platelet suspensions of $\sim 0.75-1.0 \times 10^{9}$ cells $/ \mathrm{ml}$ were collected from the column.

SDS-PAGE analysis of platelet protein phosphorylation. Reactions of ${ }^{32} \mathrm{PO}_{4}$ labeled platelets with plasmin or thrombin, as described below, were stopped by addition of a solution of $10 \%$ glycerol, $0.7 \mathrm{M} 2$-mercaptoethanol, 3\% SDS, $0.0625 \mathrm{M}$ Tris-base, $\mathrm{pH}$ 6.8, and bromphenol blue tracking dye ( $25 \mu$ l stopping solution per $40 \mu$ l platelets); the platelets were immediately placed in a boiling water bath for $3 \mathrm{~min}$. The platelet proteins were separated by $13.5 \%$ PAGE in the presence of $0.1 \%$ SDS, according to Laemmli (14). The gels were stained with $0.1 \%$ Coomassie Brilliant Blue dye, destained, and the apparent molecular weights of the protein bands were determined by calibrating the gels with standard proteins of known molecular weight. Following autoradiography, the gels were sliced into $1-\mathrm{cm}$ sections and dissolved by shaking in $0.5 \mathrm{ml}$ of $30 \%$ hydrogen peroxide at $60^{\circ} \mathrm{C}$ for $4 \mathrm{~h}$ for determination of ${ }^{32} \mathrm{P}$ by liquid scintillation spectroscopy.

Release of $\left[{ }^{3} \mathrm{H}\right]$ arachidonic acid. PRP $(5.5 \mathrm{ml})$ was incubated for $15 \mathrm{~min}$ at $37^{\circ} \mathrm{C}$ with $6.25 \mu \mathrm{Ci}\left[{ }^{3} \mathrm{H}\right]$ arachidonic acid bound to $10 \%$ bovine serum albumin (essentially fatty acid free); this permitted maximal incorporation of $\left[{ }^{3} \mathrm{H}\right]$ arachidonic acid into platelet membrane phospholipids, as described by Rittenhouse-Simmons et al. (15). The labeled PRP was gel-filtered to remove unincorporated $\left[{ }^{3} \mathrm{H}\right]$ arachidonic acid. After additions of plasmin, thrombin, or control buffer blank, the reacted platelet suspensions were pelleted by centrifugation at $8,700 \mathrm{~g}$ for $2 \mathrm{~min}$, and radioactivity released into the supernatant was counted.

$\left.{ }^{32} \mathrm{P}\right]$ Phosphatidic acid production. Incubations of ${ }^{32} \mathrm{PO}_{4}$-labeled platelets were terminated by adding aliquots of the platelet suspensions to $3.75 \mathrm{vol}$ chloroform/methanol (1:2). Lipids were extracted by a modified Bligh and Dyer procedure (16). The lower chloroform fraction (pooled from three extractions) was evaporated under $\mathrm{N}_{2}$ and redissolved in chloroform/methanol (1:1) to be spotted for thin-layer chromatography (TLC). Boric acid-impregnated Whatman (Clifton, NJ) LK5 Linear K silica gel plates were activated at $110^{\circ} \mathrm{C}$ for $1 \mathrm{~h}$ and cooled prior to spotting. A TLC solvent system of chloroform/methanol/water/ammonium hydroxide (120:75:8:4) was used for resolution of acidic phospholipids (17). Resolved lipids were visualized with $I_{2}$ and autoradiography was performed as above. The band corresponding to phosphatidic acid was scraped, eluted with methanol, and ${ }^{32} \mathrm{P}$ was determined by liquid scintillation spectroscopy.

$\left[{ }^{3} \mathrm{H}\right]$ Diglyceride production. Formation of $\left[{ }^{3} \mathrm{H}\right]$ diglyceride from platelet phospholipids labeled with $\left[{ }^{3} \mathrm{H}\right]$ arachidonic acid was measured as previously reported (18).

Measurement of cytosolic ionized calcium in platelets. Washed platelets were loaded with aequorin and quin 2 as previously described (19). Platelet counts were adjusted to $4 \times 10^{8} / \mathrm{ml}$. In some experiments, aequorin luminescence and aggregation were measured simultaneously in the same sample using a modified Lumiaggregometer, as described previously (20). Platelets were loaded with quin2-acetoxymethyl ester (quin2/ AM) to achieve an intracellular quin2 concentration of 1.0 to $1.6 \mathrm{mM}$. Measurement and calibration of aequorin and quin2 responses were as previously described (19); parallel control samples without aequorin or quin 2 were treated similarly. The quin2 fluorescence signals were corrected for changes in autofluorescence of control samples.

Radioimmunoassay of thromboxane $B_{2}\left(T X B_{2}\right)$. Platelets washed by gel filtration and suspended in Hepes-Tyrode's buffer were stimulated with plasmin or thrombin, as described below. The reactions were terminated at various time periods by adding aliquots to 3.75 vol chloroform/methanol (1:2). The methanol/ $\mathrm{H}_{2} \mathrm{O}$ fractions from Bligh and Dyer extractions of these samples, containing $\mathrm{TXB}_{2}$, were evaporated under $\mathrm{N}_{2}$, resuspended in radioimmunoassay phosphate-gelatin buffer $(50 \mathrm{mM}$ potassium biphosphate, $0.14 \mathrm{M} \mathrm{NaCl}$, and $0.1 \%$ gelatin, $\mathrm{pH} 6.8$ ) and, following appropriate dilutions, the amount of $\mathrm{TXB}_{2}$ was determined by standard radioimmunoassay with radioimmunoassay buffer, a 1:2,000 dilution of $\mathrm{TXB}_{2}$ antiserum, and $\sim 10,000 \mathrm{cpm}\left[{ }^{3} \mathrm{H}\right] \mathrm{TXB}_{2}$. After overnight incubation at $4^{\circ} \mathrm{C}$, charcoal-coated dextran was used to separate antibody-bound from unbound radioligand.

Materials. $\left[{ }^{3} \mathrm{H}\right]$ Arachidonic acid $(83.9 \mathrm{Ci} / \mathrm{mmol}),\left[{ }^{3} \mathrm{H}\right] \mathrm{TXB}_{2}(100-$ $150 \mathrm{Ci} / \mathrm{mmol}$ ), and $5-\left[2-{ }^{14} \mathrm{C}\right]$-hydroxytryptamine (serotonin) binoxalate (40-60 mCi/mmol), and $\mathrm{Na}_{2}{ }^{51} \mathrm{CrO}_{4}$ were obtained from New England Nuclear, Boston, MA. Purified human thrombin was kindly provided by Dr. Robert D. Rosenberg; bovine thrombin was purchased from ParkeDavis, Morris Plains, NJ. TXB 2 and $\mathrm{TXB}_{2}$ antiserum were purchased from the Upjohn Co., Kalamazoo, MI. Human plasmin and S-2288 chromogenic substrate were obtained from Kabi through Helena Laboratories, Beaumont, TX; for selected experiments, Kabi plasmin was compared with human plasmin obtained from American Diagnostica, Inc., Greenwich, CT, and Boehringer Mannheim Biochemicals, Indianapolis, IN. Human alpha-2-antiplasmin was also obtained from American Diagnostica, Inc. Bovine serum albumin (essentially fatty acid-free), hirudin and Sepharose 2B-300 were obtained from Sigma Chemical Co., St. Louis, MO. Aequorin was purchased from the Mayo Foundation, 
Rochester, MN. Quin2 was obtained from Amersham Corp., Arlington Heights, IL. Water used was deionized and filtered. All chemicals were reagent grade.

\section{Results}

The aggregation of washed platelets was induced by plasmin in a dose-dependent manner. As shown in Fig. 1, partial aggregation was noted at $1.0 \mathrm{CU} / \mathrm{ml}$ and complete aggregation at $1.5 \mathrm{CU} /$ $\mathrm{ml}$ of plasmin, but the onset of aggregation following addition of plasmin was typically delayed even at the highest plasmin concentrations. Plasmin-induced aggregation was not inhibited by preincubation of the platelets with $0.5 \mathrm{mM}$ aspirin for 30 min at $37^{\circ} \mathrm{C}$ (not shown).

Plasmin $(1.0 \mathrm{CU} / \mathrm{ml})$ stimulated platelet degranulation and secretion, as indicated by the release of $\left[{ }^{14} \mathrm{C}\right]$ serotonin from washed platelets preloaded with this isotope. The secretion of $\left[{ }^{14} \mathrm{C}\right]$ serotonin induced by plasmin was slightly delayed in comparison with that induced by thrombin $(1.0 \mathrm{U} / \mathrm{ml})$, a known activator of platelet aggregation and release (Fig. 2). Plasmin, at concentrations up to $3.0 \mathrm{CU} / \mathrm{ml}$, caused $<1 \%$ platelet lysis, as measured by release of ${ }^{51} \mathrm{Cr}$.

Plasmin obtained from three different sources stimulated platelet $\left[{ }^{14} \mathrm{C}\right]$ serotonin release comparably. Preincubation of plasmin with an equimolar concentration of alpha-2-antiplasmin, which inhibited $>99 \%$ of the hydrolysis of the plasmin specific chromogenic substrate S-2288, completely blocked the plasmin-induced stimulation of $\left[{ }^{14} \mathrm{C}\right]$ serotonin release but did not affect the thrombin-induced stimulation of $\left[{ }^{14} \mathrm{C}\right]$ serotonin release. Preincubation with hirudin, which completely blocked the action of thrombin, inhibited plasmin-induced $\left[{ }^{14} \mathrm{C}\right]$ serotonin release by only $\sim 20 \%$. The same concentration of hirudin also inhibited the hydrolysis of S-2288 by $\sim 20 \%$.

When ${ }^{32} \mathrm{PO}_{4}$ labeled platelets were incubated with various concentrations of plasmin for $1 \mathrm{~min}$ at $25^{\circ} \mathrm{C}$, dose-dependent phosphorylation of the platelet 47,000 - and $20,000-\mathrm{kD}$ proteins was noted. Fig. 3 (left) shows an autoradiogram of the SDSPAGE of a representative experiment. Fig. 3 (right) shows that

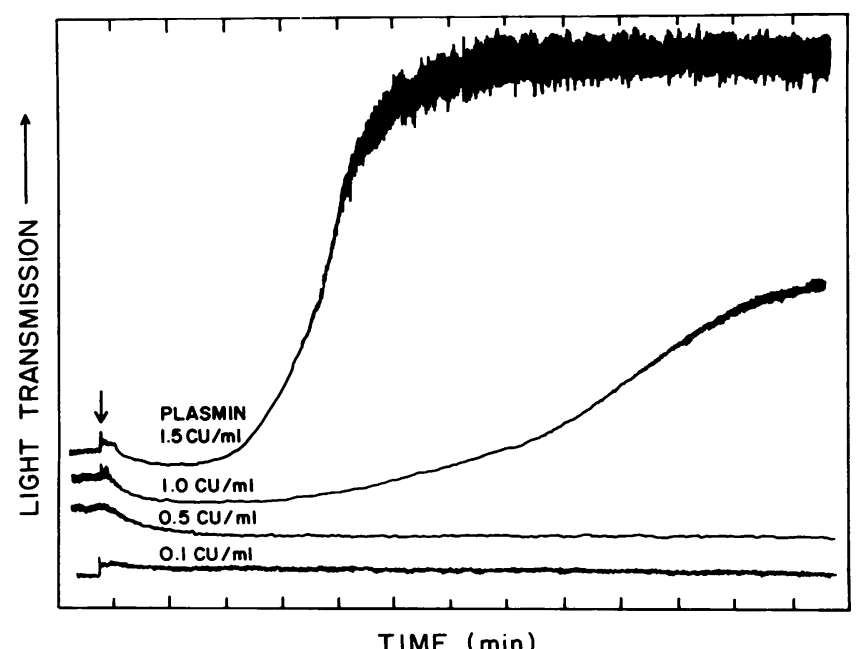

Figure 1. Platelet aggregation induced by plasmin. Platelets washed by gel filtration and suspended in a modified Tyrode's buffer (buffer A, Methods) with $0.5 \%$ albumin, were stimulated with different concentrations of plasmin (added at point of arrow). Aggregation was monitored by a standard nephelometric method.

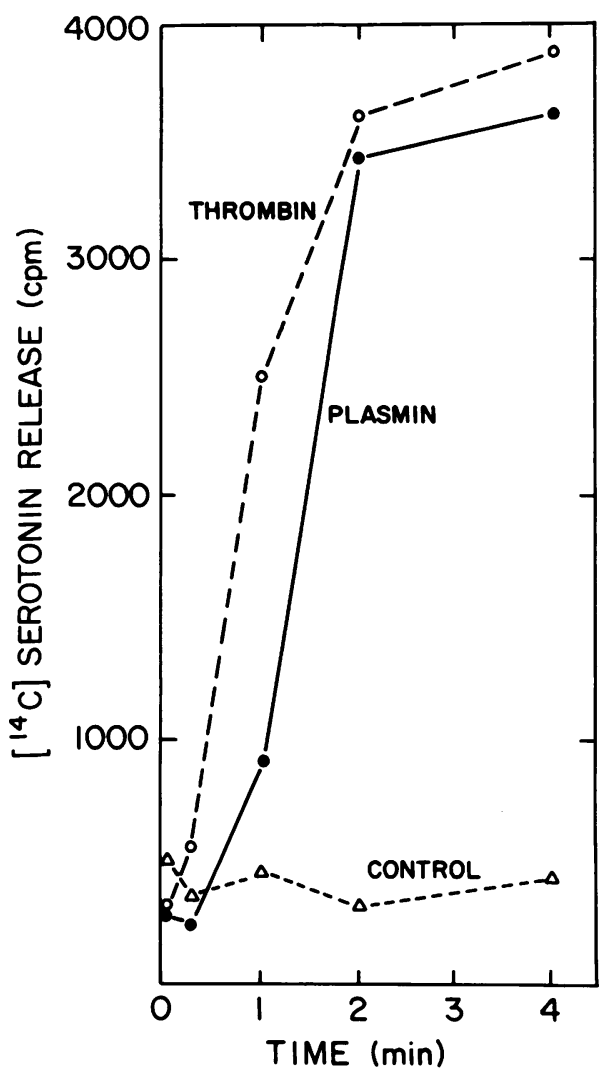

Figure 2. Platelet secretion induced by plasmin and thrombin. Washed suspensions of platelets, preloaded with $\left[{ }^{14} \mathrm{C}\right]$ serotonin, were stimulated with plasmin $(1.0 \mathrm{CU} / \mathrm{ml})$, or thrombin $(1.0 \mathrm{U} / \mathrm{ml})$, or buffer blank (control) at $37^{\circ} \mathrm{C}$ in a shaking water bath. Aliquots were withdrawn at the indicated times, release and reuptake of $\left[{ }^{14} \mathrm{C}\right]$ serotonin were stopped with formalin, and radioactivity released into the supernatants of centrifuged samples was counted.

there was maximal phosphorylation of both the 47,000 - and $20,000-\mathrm{kD}$ proteins at a concentration of $0.4 \mathrm{CU} / \mathrm{ml}$ plasmin.

The time course of phosphorylation of the 47,000- and $20,000-\mathrm{kD}$ platelet proteins induced by plasmin $(1 \mathrm{CU} / \mathrm{ml})$ and

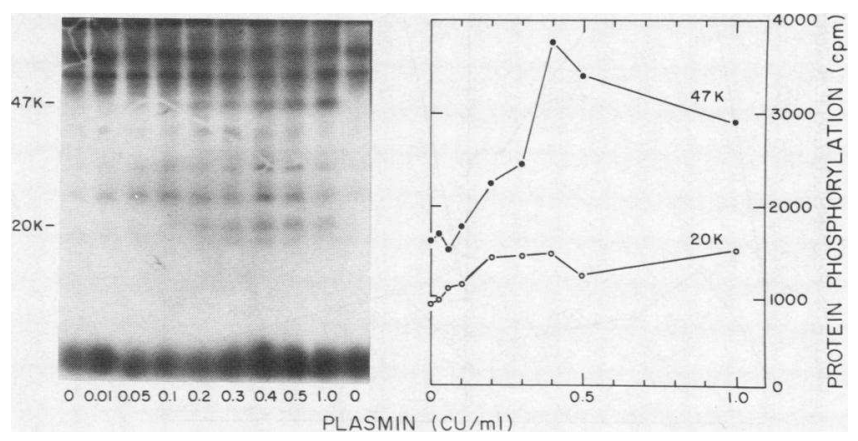

Figure 3. Platelet protein phosphorylation induced by plasmin. ${ }^{32} \mathrm{PO}_{4}-$ labeled washed platelets were stimulated with different concentrations of plasmin for $1 \mathrm{~min}$ at $25^{\circ} \mathrm{C}$ in a shaking water bath. Platelet proteins were separated by $13.5 \%$ PAGE in the presence of $0.1 \%$ SDS. A representative autoradiogram is shown in the left panel, the 47,000- and $20,000-\mathrm{kD}$ proteins being indicated by arrows. After autoradiography, the gels were sliced, digested, and the ${ }^{32} \mathrm{PO}_{4}$ incorporated into the 47,000- and 20,000-kD proteins counted (right panel). 
thrombin $(1 \mathrm{U} / \mathrm{ml})$ at $25^{\circ} \mathrm{C}$ is shown in Fig. 4. Peak ${ }^{32} \mathrm{PO}_{4}$ incorporation into both proteins occurred in response to both plasmin and thrombin at $1 \mathrm{~min}$, and this was followed by dephosphorylation. At $1 \mathrm{~min}$, there was an $\sim 2.3$ - and 3.4-fold plasmin-stimulated increase over basal phosphorylation of the 20,000- and 47,000-kD proteins, respectively, and an $\sim 3.1$ - and 3.7-fold thrombin-stimulated increase in phosphorylation of these respective proteins.

The plasmin-stimulated phosphorylation of the platelet 20,000- and 47,000-kD proteins was not affected by the extracellular $\left[\mathrm{Ca}^{2+}\right]$. As shown in Fig. 5 , the addition of $3 \mathrm{mM} \mathrm{Ca}^{2+}$ to the medium did not increase the basal (lanes 1 and 3 ) or plasmin-stimulated (lanes 2 and 4) incorporation of ${ }^{32} \mathrm{PO}_{4}$. Furthermore, $1 \mathrm{mM}$ EGTA in the medium did not inhibit the plasmin-stimulated phosphorylation of either protein (lane 5). Elevation of platelet cyclic $A M P$ inhibited protein phosphorylation in response to plasmin. Fig. 5 shows that preincubation of platelets for 5 min with $3 \mathrm{mM}$ dibutyryl cyclic AMP (dBcAMP) completely blocked the plasmin-stimulated incorporation of ${ }^{32} \mathrm{PO}_{4}$ into both the 20,000- and 47,000-kD proteins (lane 7). Preincubation with $40 \mu \mathrm{M} \mathrm{PGE}_{1}$ (lane 8 ), an activator of platelet adenylate cyclase, resulted in 80 and $85 \%$ inhibition of plasminstimulated phosphorylation of the 20,000 - and $47,000-\mathrm{kD}$ proteins, respectively. Preincubation of the platelets with $0.5 \mathrm{mM}$ aspirin for $30 \mathrm{~min}$ at $37^{\circ} \mathrm{C}$ did not inhibit plasmin-induced phosphorylation (not shown).

Comparable patterns of protein phosphorylation were seen using plasmin from three different sources. As in the $\left[{ }^{14} \mathrm{C}\right]$ serotonin release experiments, alpha-2-antiplasmin completely blocked plasmin-induced protein phosphorylation but did not inhibit thrombin-induced protein phosphorylation. Hirudin blocked thrombin-induced phosphorylation but did not inhibit plasmin-induced phosphorylation.

The finding that plasmin stimulated platelet secretion and phosphorylation of the platelet myosin light chains and 47,000$\mathrm{kD}$ protein suggested that its effects on platelets were mediated by $\mathrm{Ca}^{2+}$ translocation, stimulation of inositol phospholipid turnover and protein kinase $\mathrm{C}$ activation. Measurement of

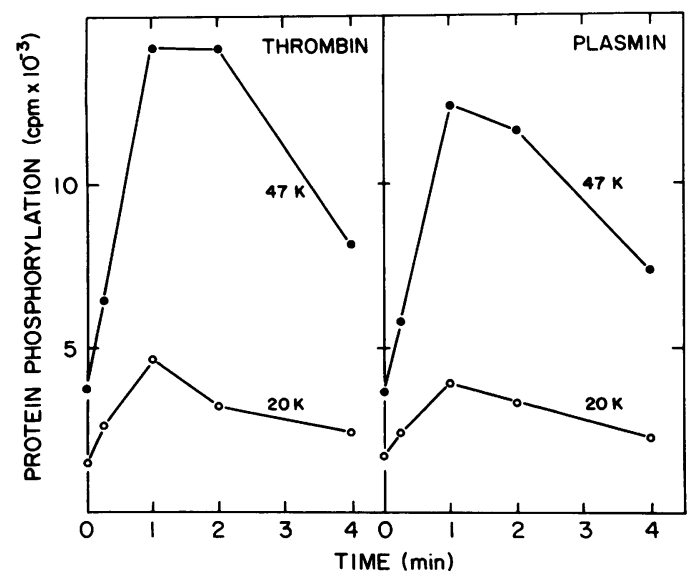

Figure 4. Time-dependent platelet protein phosphorylation induced by plasmin and thrombin. ${ }^{32} \mathrm{PO}_{4}$-labeled platelets were incubated at $25^{\circ} \mathrm{C}$ with $1.0 \mathrm{U} / \mathrm{ml}$ thrombin (left panel) or $1.0 \mathrm{CU} / \mathrm{ml}$ plasmin (right panel), and the reaction was stopped at the times indicated by the addition of aliquots to a stopping solution and boiling as described in Methods. Incorporation of ${ }^{32} \mathrm{PO}_{4}$ into the 47,000- and 20,000-kD proteins is shown.

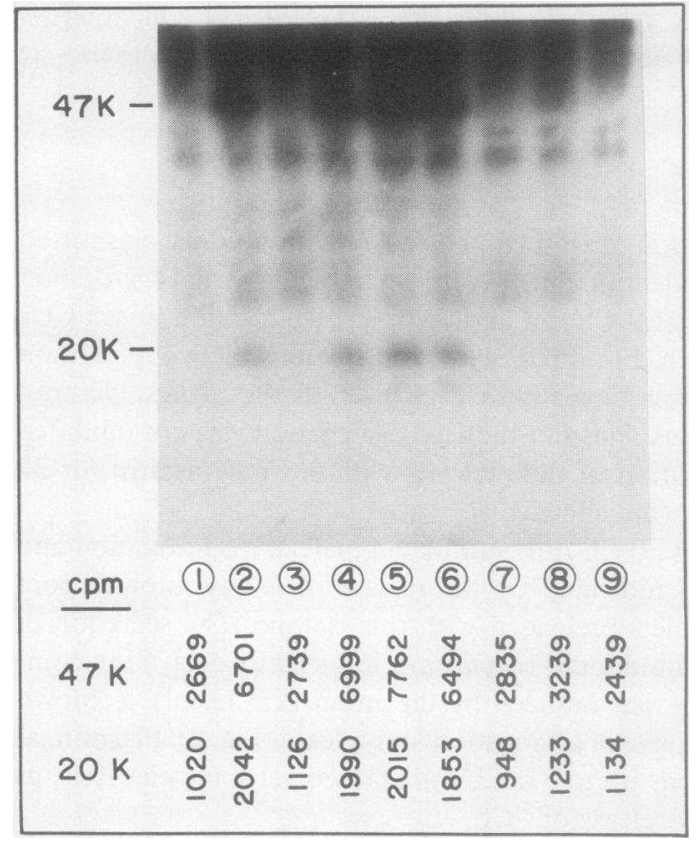

Figure 5. Effects of extracellular $\mathrm{Ca}^{2+}$ and cyclic AMP on plasmin-induced platelet protein phosphorylation. Incorporation of ${ }^{32} \mathrm{PO}_{4}$ into the 47,000 - and $20,000-\mathrm{kD}(\mathrm{K})$ proteins was determined with the following additions to Hepes-Tyrode's buffer: (1) no additions; (2) 1.0 $\mathrm{CU} / \mathrm{ml}$ plasmin; (3) $3 \mathrm{mM} \mathrm{CaCl}$; (4) $3 \mathrm{mM} \mathrm{CaCl} 2+1.0 \mathrm{CU} / \mathrm{ml}$ plasmin; (5) $1 \mathrm{mM}$ EGTA + 1.0 CU/ml plasmin; (6) $0.5 \mathrm{mM} \mathrm{dBcAMP} \mathrm{(5}$ min preincubation) $+1.0 \mathrm{CU} / \mathrm{ml}$ plasmin; (7) $3 \mathrm{mM} \mathrm{dBcAMP} \mathrm{(5} \mathrm{min}$ preincubation $+1.0 \mathrm{CU} / \mathrm{ml}$ plasmin; (8) $40 \mu \mathrm{M} \mathrm{PGE}_{1}(5 \mathrm{~min}$ preincubation) $+1.0 \mathrm{CU} / \mathrm{ml}$ plasmin; (9) no additions. The autoradiogram is shown on top and the counts per minute of ${ }^{32} \mathrm{PO}_{4}$ incorporated into the 47,000 - and $20,000-\mathrm{kD}$ proteins are shown under each corresponding lane.

platelet ionized calcium concentration $\left(\left[\mathrm{Ca}_{i}{ }^{2+}\right]\right)$ in real time, as indicated by quin2 fluorescence, is shown in Fig. 6. Plasmin (1.0 $\mathrm{CU} / \mathrm{ml}$ ) caused an increase in $\left[\mathrm{Ca}_{\mathrm{i}}{ }^{2+}\right]$ from a basal level of 0.58 $\times 10^{-7} \mathrm{M}$ to a peak of $1.35 \times 10^{-7} \mathrm{M}$. Control platelets stirred in parallel without plasmin addition showed no rise in $\left[\mathrm{Ca}_{\mathrm{i}}{ }^{2+}\right]$

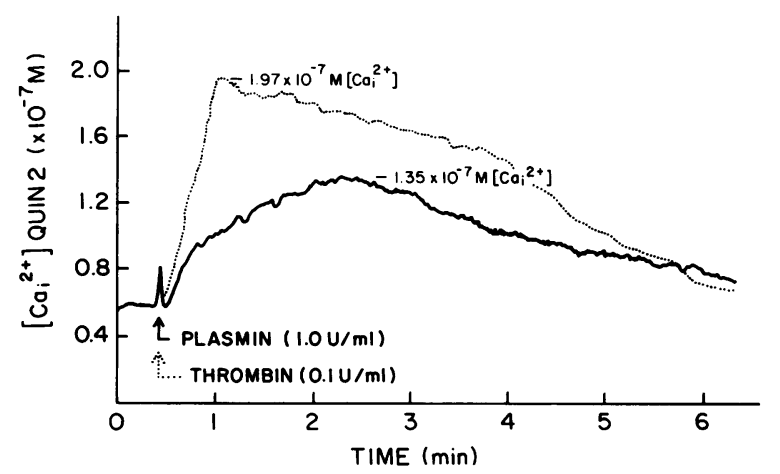

Figure 6. Quin2-indicated platelet $\left[\mathrm{Ca}_{\mathrm{i}}{ }^{2+}\right]$ in response to plasmin $(1.0$ $\mathrm{CU} / \mathrm{ml})$ or thrombin $(0.1 \mathrm{U} / \mathrm{ml})$. Washed platelets $\left(1 \times 10^{8} / \mathrm{ml}\right)$ preloaded with quin 2 were suspended in Hepes-Tyrode's buffer containing $1 \mathrm{mM} \mathrm{Ca}^{2+}$. Platelets were stimulated with plasmin or thrombin, and quin2 fluorescence signals were continuously monitored. Both agonists caused a small decrease in autofluorescence of platelets not loaded with quin2, which was added to the quin2 signal before calibration. 
during this period (not shown). For comparison, Fig. 6 also shows the response of platelets to thrombin $(0.1 \mathrm{U} / \mathrm{ml})$, a known platelet activator. Using either quin2 (Fig. 7) or aequorin (Fig. 8) as the indicator, plasmin induced a rise in $\left[\mathrm{Ca}_{i}{ }^{2+}\right]$ to which both intracellular and extracellular $\mathrm{Ca}^{2+}$ contributed: an increase in $\left[\mathrm{Ca}_{\mathrm{i}}{ }^{2+}\right]$ was noted with plasmin concentrations $\geq 0.1 \mathrm{CU} / \mathrm{ml}$ in medium containing $\mathrm{Ca}^{2+}$ and, to a lesser extent, $\geq 0.5 \mathrm{CU} / \mathrm{ml}$ in medium containing EGTA. A rise in $\left[\mathrm{Ca}_{\mathrm{i}}{ }^{2+}\right]$ in response to $\geq 0.5 \mathrm{CU} / \mathrm{ml}$ plasmin in the presence of $2 \mathrm{mM}$ EGTA in the extracellular medium indicates that plasmin stimulates intracellular $\mathrm{Ca}^{2+}$ mobilization.

In order to examine the effect of plasmin on the hydrolysis of endogenous platelet arachidonic acid by phospholipase(s), platelet membrane phospholipid pools were labeled with $\left[{ }^{3} \mathrm{H}\right]$ arachidonic acid and then stimulated with plasmin: the radioactivity released into the supernatant at various time intervals was then counted. As shown in Table $\mathrm{I}, 0.1 \mathrm{CU} / \mathrm{ml}$ plasmin stimulated no $\left[{ }^{3} \mathrm{H}\right]$ arachidonic acid release in excess of basal levels. However, $1.0 \mathrm{CU} / \mathrm{ml}$ plasmin did cause a modest, timedependent mobilization of endogenous arachidonic acid. (The response to thrombin, a known platelet phospholipase activator, is shown for comparison.) To test the effect of plasmin on activation of platelet phospholipase $\mathrm{C}$, platelets labeled with $\left[{ }^{3} \mathrm{H}\right]$ arachidonic acid and ${ }^{32} \mathrm{PO}_{4}$ were stimulated with plasmin for various time intervals, and the formation of $\left[{ }^{3} \mathrm{H}\right]$ diglyceride (DG) and [ $\left.{ }^{32} \mathrm{P}\right]$ phosphatidic acid (PA) were monitored by TLC. As shown in Fig. 9, plasmin induced the rapid and transient production of diglyceride, followed by the generation of phosphatidic acid. In contrast to thrombin, which rapidly stimulated the formation of large amounts of thromboxane $\mathrm{A}_{2}\left(\mathrm{TXA}_{2}\right)$ in platelets, the production of $\mathrm{TXA}_{2}$ (measured by radioimmunoassay of $\mathrm{TXB}_{2}$ ) in response to $1.0 \mathrm{CU} / \mathrm{ml}$ plasmin was very small and markedly delayed (Table II). Increasing the plasmin concentration up to $3.0 \mathrm{CU} / \mathrm{ml}$ did not enhance $\mathrm{TXB}_{2}$ production (data not shown).

\section{Discussion}

Synergistic interactions are known to occur between thrombin generation and platelet activation, which amplify and localize formation of the hemostatic plug at the site of vascular injury

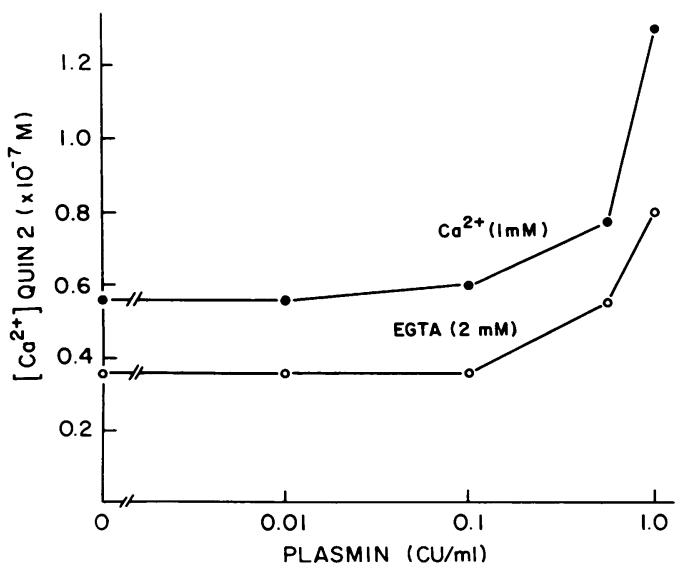

Figure 7. Peak $\left[\mathrm{Ca}_{\mathrm{i}}{ }^{2+}\right]$ signals as indicated by quin 2 in response to increasing concentrations of plasmin. The points represent values obtained in media containing $1 \mathrm{mM} \mathrm{Ca}^{2+}$ with or without $2 \mathrm{mM}$ EGTA. Changes in autofluorescence were subtracted or added to the quin2 signals before calibration as previously described (22).

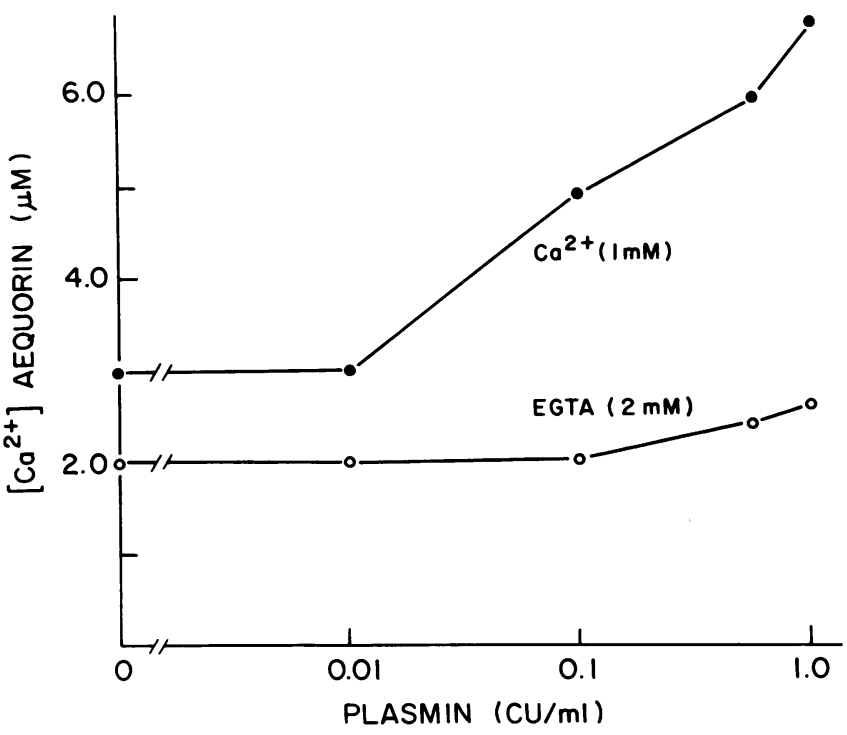

Figure 8. Peak $\left[\mathrm{Ca}_{\mathrm{i}}{ }^{2+}\right]$ signals as indicated by aequorin in response to increasing concentrations of plasmin. The points represent values obtained in media containing $1 \mathrm{mM} \mathrm{Ca}^{2+}$ with or without $2 \mathrm{mM}$ EGTA. As previously noted (22), the unstimulated basal level of $\left[\mathrm{Ca}_{\mathrm{i}}{ }^{2+}\right]$ reported by aequorin is probably not indicative of the true mean $\left[\mathrm{Ca}_{i}{ }^{2+}\right]$.

(21). Evidence is now accumulating to suggest that similar interactions may occur between plasmin and platelets to promote and localize clot lysis. Platelets actively contribute to fibrinolysis by serving as sites for the specific binding of plasminogen, accelerating the activation of plasminogen to plasmin (22), and contributing to the regulation of the fibrinolytic system (23-26). Conversely, plasmin may also affect platelet function. Plasmin induces the loss of platelet membrane glycoprotein Ib and thereby the ristocetin-mediated responsiveness of platelets to the adhesive protein, Factor VIII:von Willebrand factor (2). Furthermore, we have recently reported that plasmin inhibits the reactivity of platelets to membrane-active agonists such as thrombin, collagen, and calcium ionophore (3). At higher concentrations, plasmin itself has been shown to directly induce platelet activation (2729). The present study was designed to investigate the biochemical mechanism of platelet stimulation by plasmin.

The results of this study suggest that plasmin stimulates platelet secretion through mechanisms involving activation of

Table I. Plasmin- and Thrombin-induced Release of $\left[{ }^{3}\right]$ Arachidonic Acid $(A A)$

\begin{tabular}{llll}
\hline & \multicolumn{3}{l}{$\left[{ }^{3} \mathrm{H}\right] \mathrm{AA}$ released at } \\
\cline { 2 - 4 } Stimulus & $15 \mathrm{~s}$ & $2 \mathrm{~min}$ & $5 \mathrm{~min}$ \\
\hline 0 & $0.98 \pm 0.03$ & $1.00 \pm 0.04$ & $1.04 \pm 0.05$ \\
Plasmin, $0.1 \mathrm{CU} / \mathrm{ml}$ & $0.70 \pm 0.01$ & $0.73 \pm 0.02$ & $0.84 \pm 0.05$ \\
Plasmin, $1.0 \mathrm{CU} / \mathrm{ml}$ & $1.05 \pm 0.01$ & $1.11 \pm 0.06$ & $1.68 \pm 0.07$ \\
Thrombin, $1.0 \mathrm{U} / \mathrm{ml}$ & $2.10 \pm 0.04$ & $9.97 \pm 0.09$ & $9.35 \pm 0.37$
\end{tabular}

Platelet membrane phospholipids were labeled with [ $\left.{ }^{3} \mathrm{H}\right] \mathrm{AA}$, gel filtered to eliminate unincorporated radioactivity, and then incubated at $37^{\circ} \mathrm{C}$ with buffer blank, plasmin $(0.1$ or $1.0 \mathrm{CU} / \mathrm{ml})$, or thrombin $(1.0$ $\mathrm{U} / \mathrm{ml}$ ). Radioactivity released into the supernatant at various intervals was counted. Data are mean \pm SEM of six measurements representing three experiments. 


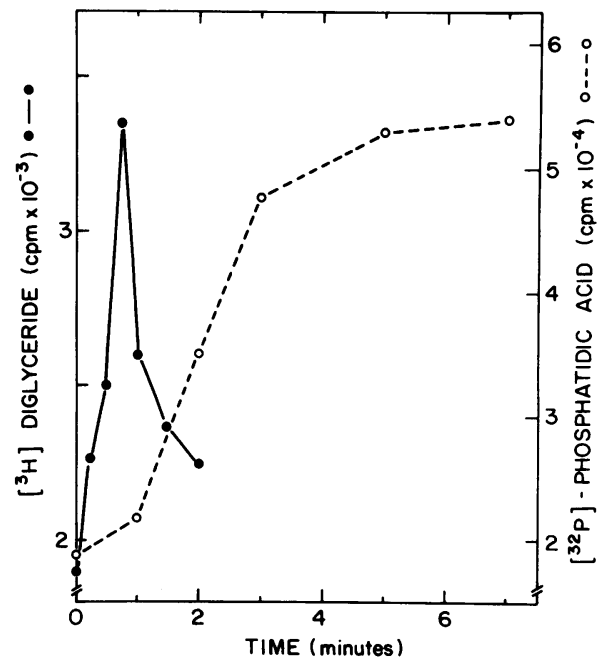

Figure 9. Plasmin-induced platelet diglyceride and phosphatidic acid formation. Platelets labeled with $\left[{ }^{3} \mathrm{H}\right]$ arachidonic acid or ${ }^{32} \mathrm{PO}_{4}$ were stimulated with $1.0 \mathrm{CU} / \mathrm{ml}$ plasmin in a shaking water bath. Reactions were stopped at the time periods shown with 3.75 vol chloroform/methanol (1:2). Extractions and TLC resolution of $\left[{ }^{3} \mathrm{H}\right]$ diglyceride and $\left[{ }^{32} \mathrm{P}\right]$ phosphatidic acid were performed as described in Methods.

phospholipid dependent protein kinase $\mathrm{C}$ and possibly $\mathrm{Ca}^{2+}$ calmodulin dependent protein kinases. It has been proposed that protein kinase $\mathrm{C}$ activation and $\mathrm{Ca}^{2+}$ mobilization act synergistically to elicit a full biologic response (4), in this case platelet degranulation and aggregation. A marked delay is observed in the onset of plasmin-induced platelet aggregation (Fig. 1) compared to the plasmin-induced initiation of secretion (Fig. 2). Since interaction between fibrinogen and membrane fibrinogen receptors is required for the aggregation response of platelets, this discrepancy between aggregation and secretion is most readily explained by plasmin proteolysis of fibrinogen released from platelets and possibly also the plasmin cleavage of platelet fibrinogen receptors.

We have demonstrated that plasmin can directly raise the platelet cytosolic $\mathrm{Ca}^{2+}$ concentration. This was shown using

Table II. Plasmin- and Thrombin-induced Platelet $T X B_{2}$ Production

\begin{tabular}{cll}
\hline & \multicolumn{2}{l}{ Thromboxane $\mathrm{B}_{2}(\mathrm{ng} / \mathrm{ml})$} \\
\cline { 2 - 3 } Time & \multicolumn{1}{l}{ Plasmin } & \multicolumn{1}{c}{ Thrombin } \\
\hline $\min$ & & \\
0 & $2.15 \pm 0.55$ & $2.83 \pm 1.40$ \\
2 & $2.39 \pm 0.58$ & $46.26 \pm 5.08$ \\
5 & $2.66 \pm 0.91$ & $85.67 \pm 3.91$ \\
10 & $4.38 \pm 1.02$ & ND \\
\end{tabular}

Washed platelets (platelet counts $6-7 \times 10^{9} / \mathrm{ml}$ ) were stimulated with plasmin $(1.0 \mathrm{CU} / \mathrm{ml})$ or thrombin $(1.0 \mathrm{U} / \mathrm{ml})$, and stirred at $25^{\circ} \mathrm{C}$. Reactions were terminated at various times by addition of aliquots to $3.75 \mathrm{vol} \mathrm{chloroform} / \mathrm{methanol}$ (1:2), and extracted and analyzed for $\mathrm{TXB}_{2}$ by radioimmunoassay as described in Methods. Data are mean \pm SEM of quadruplicate determinations representing three experiments. quin2 as an indicator, and confirmed by aequorin luminescence, which may be particularly sensitive to localized $\left[\mathrm{Ca}_{\mathrm{i}}{ }^{2+}\right]$ changes (19). Plasmin may increase $\left[\mathrm{Ca}_{\mathrm{i}}{ }^{2+}\right]$ by several mechanisms. It mobilizes $\mathrm{Ca}^{2+}$ from intracellular stores since the quin 2 and aequorin signals were detected even with EGTA in the medium, but may also induce movement of $\mathrm{Ca}^{2+}$ inward across the plasma membrane since EGTA blunted the signals. Plasmin may exert a direct effect on platelet membrane $\mathrm{Ca}^{2+}$ channels and increase the permeability of the plasma membrane to $\mathrm{Ca}^{2+}$. The plasmininduced $\mathrm{Ca}^{2+}$ mobilization may also be mediated by $\mathrm{IP}_{3}$ generated through inositol phospholipid breakdown $(30,31)$.

The results of this study suggest that plasmin may not act simply as a calcium ionophore, since it clearly causes activation of phospholipase C. Phosphorylation of the $47,000-\mathrm{kD}$ protein indicates plasmin induced activation of protein kinase $C$. Phosphorylation of the $20,000-\mathrm{kD}$ protein may be due to plasmininduced calmodulin-dependent activation of myosin light chain kinase (4), but the $20,000-\mathrm{kD}$ protein can also be phosphorylated by protein kinase $C(32)$. Inhibition of phosphorylation of the 47,000- and 20,000-kD proteins by elevation of platelet cyclic AMP with either ABcAMP or $\mathrm{PGE}_{1}$ is consistent with the role of cyclic AMP as a negative messenger to inhibit the effect of plasmin and other positive agonists that stimulate platelet aggregation and secretion.

Since the ability of plasmin to phosphorylate the platelet $47,000-\mathrm{kD}$ protein implies diacylglycerol generation and protein kinase $\mathrm{C}$ activation, we performed experiments to demonstrate plasmin induced inositol phospholipid breakdown. The release of $\left[{ }^{3} \mathrm{H}\right]$ arachidonic acid from platelet membrane phospholipids provided evidence for the stimulation of phospholipase activity by plasmin. To demonstrate phospholipase $\mathrm{C}$ activation, we have shown that plasmin causes the formation of diacylglycerol and subsequently phosphatidic acid. It is of interest that although plasmin initiates inositol phospholipid turnover, there is very little thromboxane $\mathrm{A}_{2}\left(\mathrm{TXA}_{2}\right)$ produced. This could be due simply to the relatively low potency of plasmin as an activator of phospholipase C. However, there may also be an uncoupling of phospholipase $\mathrm{C}$ activation and arachidonic acid metabolism. It has been previously shown that polymerization of actin in platelets stimulated by thrombin is required for the effective metabolism of arachidonic acid released from phospholipids (33), and it is possible that plasmin may degrade cytoskeletal proteins that are required to affect actin polymerization. The biologic response to plasmin in platelets is clearly not mediated by $\mathrm{TXA}_{2}$, since its formation is delayed well beyond the time that full plasmin-induced aggregation and release are attained. Furthermore, plasmin stimulated platelet aggregation and protein phosphorylation are unaffected by prior incubation with aspirin, which inhibits $\mathrm{TXA}_{2}$ production.

In summary, we have found that plasmin can act as a direct platelet agonist, stimulating platelet secretion by inducing an elevation in cytosolic $\mathrm{Ca}^{2+}$. This action of plasmin on platelets is associated with inositol phospholipid turnover and activation of protein kinase C. Plasmin stimulates maximal platelet protein phosphorylation to an extent comparable to that of thrombin, and plasmin is as potent a platelet secretagogue as thrombin. However, in its hemostatic actions plasmin is a weak agonist for platelets when compared with thrombin. Aggregation following exposure of platelets to plasmin is delayed and accompanied by the formation of only small amounts of the vasoconstrictor $\mathrm{TXA}_{2}$. In fact, plasmin at lower concentrations is a potent inhibitor of platelet aggregation and $\mathrm{TXA}_{2}$ production induced 
by thrombin (3) and it inhibits platelet adhesion by hydrolyzing platelet membrane glycoprotein Ib (2). Although circulating levels of plasmin approaching those causing these in vitro effects on platelets are theoretically attainable in vivo under pathologic or pharmacologic conditions, plasmin more likely exerts these actions on platelets locally at the site of clot formation where concentrations are probably amplified. The complex effects of plasmin on platelet function may play an important role in modulating dissolution of the hemostatic plug.

\section{Acknowledgments}

We thank Mary Halm Small for expert secretarial assistance in preparation of this manuscript.

This work was supported by National Institutes of Health grants HL27465, HL-25066, HL-29316, and HL-27897, and a grant-in-aid from the American Heart Association with funds contributed in part by the Massachusetts Affiliate. Dr. Schafer and Dr. Rittenhouse are Established Investigators of the American Heart Association.

\section{References}

1. Collen, D. 1980. On the regulation and control of fibrinolysis. Thromb. Haemostasis. 43:77-89.

2. Adelman, B., A. D. Michelson, J. Loscalzo, J. Greenberg, and R. I. Handin. 1985. Plasmin effect on platelet glycoprotein Ib-von Willebrand's factor interaction. Blood. 65:32-40.

3. Schafer, A. I., and B. Adelman. 1985. Plasmin inhibition of platelet function and of arachidonic acid metabolism. Effects on hemostasis. $J$. Clin. Invest. 75:456-461.

4. Nishizuka, Y. 1984. The role of protein kinase $C$ in cell surface signal transduction and tumour promotion. Nature (Lond.). 308:693698.

5. Exton, J. H. 1985. Role of calcium and phosphoinositides in the actions of certain hormones and neurotransmitters. J. Clin. Invest. 75: 1753-1757.

6. Sgouris, J. T., J. K. Inman, K. B. McCall, L. A. Hyndman, and H. D. Anderson. 1960. The preparation of human fibrinolysin (plasmin). Vox Sang. 5:357-376.

7. Friberger, P., M. Knos, S. Gustavsson, L. Aurell, and G. Claeson. 1979. A new specific substrate for the determination of plasmin activity. In Chromogenic Peptide Substrates. M. F. Scully and V. V. Kakkar, editors. Churchill Livingston, London.

8. Kabi Diagnostica Data Sheet for S-2288.

9. Born, G. V. R., and M. J. Cross. 1963. The aggregation of blood platelets. J. Physiol. 168:178-195.

10. Jerushalmy, W., and M. B. Zucker. 1966. Some effects of fibrinogen degradation products (FDP) or blood platelets. Thromb. Diath. Haemorrh. 15:413-419.

11. Costa, J. L., and D. L. Murphy. 1975. Platelet 5-HT uptake and release stopped rapidly by formaldehyde. Nature (Lond.). 255:407-408.

12. Steiner, M., and M. Baldini. 1970. Subcellular distribution of ${ }^{51} \mathrm{Cr}$ and characterization of its binding sites in human platelets. Blood. 35:727-739.

13. Kinlough-Rathbone, R. L., A. Chahil, M. A. Packham, and J. F. Mustard. 1975. Conditions influencing platelet lysis. Lab. Invest. 32:352-358
14. Laemmli, U. K. 1970. Cleavage of structural proteins during the assembly of the head of bacteriophage T4. Nature (Lond.). 227:680-685.

15. Rittenhouse-Simmons, S., F. A. Russell, and D. Deykin. 1976. Transfer of arachidonic acid to human platelet plasmalogen in response to thrombin. Biochem. Biophys. Res. Commun. 70:295-301.

16. Rittenhouse-Simmons, S. 1981. Differential activation of platelet phospholipases by thrombin and ionophore A23187. J. Biol. Chem. 256: 4153-4155.

17. Rittenhouse, S. E. 1983. Human platelets contain phospholipase C that hydrolyzes phosphoinositides. Proc. Natl. Acad. Sci. USA. 80: 5417-5420.

18. Rittenhouse-Simmons, S. 1979. Production of diglyceride from phosphatidylinositol in activated human platelets. J. Clin. Invest. 63: 580-587.

19. Johnson, P. C., J. A. Ware, P. B. Cliveden, M. Smith, A. M. Dvorak, and E. W. Salzman. 1985. Measurement of ionized calcium in blood platelets with the photoprotein aequorin. Comparison with quin2. J. Biol. Chem. 260:2069-2076.

20. Johnson, P. C., J. A. Ware, and E. W. Salzman. 1985. Concurrent measurement of platelet ionized calcium concentrates and aggregation: studies with the lumiaggregometer. Thromb. Res. 40:435-439.

21. Mann, K. 1984. Membrane-bound enzyme complexes in blood coagulation. In Progress in Hemostasis and Thrombosis. T. H. Spaet, editor. Grune \& Stratton, Inc., Orlando. 7:1-23.

22. Miles, L. A., and E. F. Plow. 1985. Binding and activation of plasminogen on the platelet surface. J. Biol. Chem. 260:4303-4311.

23. Taylor, F. B., Jr., and J. H. Muller-Eberhard. 1970. Qualitative description of factors involved in the retraction and lysis of dilute whole blood clots and in aggregation and retraction of platelets. J. Clin. Invest. 49:2068-2085.

24. Lockhart, M., P. C. Comp, and F. B. Taylor, Jr. 1979. Role of platelets in lysis of dilute plasma clots: requirement for metabolically active platelets. J. Lab. Clin. Med. 94:285-294.

25. Carroll, R. C., J. M. Gerrard, and J. M. Gilliam. 1981. Clot retraction facilitates clot lysis. Blood. 57:44-48.

26. Carroll, R. C., R. D. Radcliffe, F. B. Taylor, Jr., and J. M. Gerrard. 1982. Plasminogen, plasminogen activator, and platelets in the regulation of clot lysis. J. Lab. Clin. Med. 100:986-996.

27. Niewiarowski, S., A. F. Senyi, and P. Gillies. 1973. Plasmininduced platelet aggregation and platelet release reaction. J. Clin. Invest. 52:1647-1659.

28. Miller, J. L., A. J. Katz, and M. B. Feinstein. 1975. Plasmin inhibition of thrombin-induced platelet aggregation. Thromb. Diath. Haemorrh. 33:286-309.

29. Griguer, P., Mireille-Brochier, J. Leroy, M.-H. Leclerc, H. Bertrand, and F. Chalons. 1980. Platelet aggregation after thrombolytic therapy. Angiology. 31:91-99.

30. Michell, R. H. 1975. Inositol phospholipids and cell surface receptor function. Biochim. Biophys. Acta. 415:81-147.

31. Berridge, M. J. 1984. Inositol trisphosphate and diacylglycerol as second messengers. Biochem. J. 220:345-360.

32. Naka, M., M. Mishikawa, R. S. Adelstein, and H. Hidaka. 1983. Phorbol ester-induced activation of human platelets is associated with protein kinase $\mathrm{C}$ phosphorylation of myosin light chain. Nature (Lond.). 306:490-492.

33. Siess, W., E. G. Lapetina, and P. Cuatrecasas. 1982. Cytochalasins inhibit arachidonic acid metabolism in thrombin stimulated platelets. Proc. Natl. Acad. Sci. USA. 79:7709-7713. 